\title{
Body-size dependent temporal variations in nitrogen stable isotope ratios in food webs
}

\author{
Simon Jennings ${ }^{1,2, *}$, Tracy A. D. Maxwell ${ }^{1}$, Michaela Schratzberger ${ }^{1}$, Steve P. Milligan ${ }^{1}$ \\ ${ }^{1}$ Centre for Environment, Fisheries \& Aquaculture Science, Lowestoft Laboratory, Lowestoft NR33 0HT, UK \\ ${ }^{2}$ School of Environmental Sciences, University of East Anglia, Norwich NR4 7TJ, UK
}

\begin{abstract}
We describe seasonal variation in nitrogen stable isotope ratios of marine animals (zooplankton, benthic infauna, benthic epifauna and fishes) in size-fractionated classes spanning 6 orders of magnitude in body mass. Variation in $\delta^{15} \mathrm{~N}$ over the course of the seasonal production cycle was significantly greater in smaller animals and declined continuously with increasing body size. The duration and magnitude of a decrease in $\delta^{15} \mathrm{~N}$ (as observed in the zooplankton community at the start of the production cycle) was reduced and attenuated in larger animals at higher trophic levels (higher mean $\delta^{15} \mathrm{~N}$ ), likely reflecting different rates of energy propagation in different food web pathways and the transfer of energy to animals with slower turnover times. Animals $\geq 16 \mathrm{~g}$ wet body mass integrated seasonal variation in $\delta^{15} \mathrm{~N}$ of their prey, such that a single annual sampling of animals in size classes $\geq 16 \mathrm{~g}$ was sufficient to determine mean $\delta^{15} \mathrm{~N}$. For zooplankton and smaller infauna, very frequent sampling would be required to estimate mean $\delta^{15} \mathrm{~N}$, and we show that measurements of food web properties such as trophic position and predator-prey size ratios would be biased when based on single samples of these small animals.
\end{abstract}

KEY WORDS: Food web $\cdot$ Body size $\cdot$ Stable isotope analysis $\cdot$ Temporal variation $\cdot$ Stoichiometry

\section{INTRODUCTION}

Stable isotope analyses are used to describe food web interactions and the energy sources and pathways that support production (Owens 1987, Fry 2006). For the results of these analyses to describe average food web properties, typically over a minimum period of a season or year, sampling design should account for the ecology and dynamics of the animals sampled (Vizzini \& Mazzola 2003, Matthews \& Mazumder 2005, 2007). This requirement is rarely addressed explicitly, and stable isotope data for single samples of animals that could be responding to transient events are often used to draw conclusions about their longer-term role in food webs.

The nitrogen stable isotope composition $\left(\delta^{15} \mathrm{~N}\right)$ of sampled animals responds to differences in $\delta^{15} \mathrm{~N}$ among diets and variability of $\delta^{15} \mathrm{~N}$ within the same diet (Fry 2006). The former response accounts for the value of $\delta^{15} \mathrm{~N}$ in food web studies, while the latter response, if not known or accounted for, can confound analysis and interpretation (e.g. Cabana \& Rasmussen 1996, Vander Zanden \& Rasmussen 1999, O'Reilly et al. 2002).

The changing nutrient sources that support phytoplankton production lead to seasonal variations in $\delta^{15} \mathrm{~N}$ that can be detected in their zooplankton predators (Goering et al. 1990, Montoya et al. 1990, Yoshioka et al. 1994, Rolff 2000, Bode et al. 2003, 2007, Bode \& AlvarezOssorio 2007). For example, during a Baltic Sea production cycle, a depleted nitrogen isotopic signal was propagated through all size classes of plankton in the summer, indicating the use of nitrogen fixed by Cyanobacteria (Rolff 2000). In general, seasonal variations in phytoplankton $\delta^{15} \mathrm{~N}$ are driven by the differential use of ammonium and nitrate that occurs during the production cycle (Weston et al. 2004). There may also be considerable variation in the $\delta^{15} \mathrm{~N}$ of primary producers in dynamic environments such as estuaries, due to seasonal variability in the relative contribution of marine and terrestrial nitrogen sources (Sato et al. 2006). 
Animals with smaller body sizes have higher metabolic rates and faster turnover times than larger animals. Small animal isotopic composition will therefore respond more rapidly to changes in dietary $\delta^{15} \mathrm{~N}$ than that of larger animals. This has long been recognised and explains why estimates of trophic level calculated from $\delta^{15} \mathrm{~N}$ are usually referenced to the 'base' $\delta^{15} \mathrm{~N}$ of animals that integrate some of the seasonal variation in the $\delta^{15} \mathrm{~N}$ of primary producers (e.g. Cabana \& Rasmussen 1996, Vander Zanden \& Rasmussen 1999). Filter-feeding bivalves have been used for this purpose (Goering et al. 1990, Lorrain et al. 2002).

The determination of 'base' $\delta^{15} \mathrm{~N}$, however, is only part of the process needed to estimate a representative mean $\delta^{15} \mathrm{~N}$ for other animals, since these animals should also be sampled with sufficient frequency to calculate a valid mean $\delta^{15} \mathrm{~N}$. A more systematic approach to understanding the necessary sampling frequency would be to examine the relationship between variance in $\delta^{15} \mathrm{~N}$ and body size and to estimate the sampling frequencies necessary to account for changes in the temporal variation in $\delta^{15} \mathrm{~N}$ with body size. Size rather than species identity is treated as the relevant variable here, because body size is often a better predictor of trophic position than species identity in marine food webs (Jennings et al. 2002a), and body size determines rates of metabolism and production (Brown et al. 2004), which influence tissue turnover time (Fry 2006). The expectation is that any seasonal $\delta^{15} \mathrm{~N}$ signal propagating through the food web will be attenuated as it passes to larger animals at higher trophic levels and with longer turnover times.

Here, we examine relationships between body size and $\delta^{15} \mathrm{~N}$ variation in a marine food web, based on repeated sampling of the web during a production cycle. Our aims were (1) to describe seasonal stable isotope dynamics for zooplankton, benthic invertebrates and fish spanning 6 orders of magnitude in body mass, (2) to use this information to better understand the biases introduced by ignoring seasonal dynamics in food web studies and (3) to identify body sizes and groups for which $\delta^{15} \mathrm{~N}$ estimates at any point in time reflect the seasonal mean.

\section{MATERIALS AND METHODS}

Sampling was conducted at sites in the 'Silver Pit', central North Sea (all within the area $54^{\circ} 00^{\prime}$ to $54^{\circ} 10^{\prime} \mathrm{N}$ and $01^{\circ} 50^{\prime}$ to $02^{\circ} 50^{\prime} \mathrm{E}$ ) at depths of 58 to $75 \mathrm{~m}$. The same sampling protocol was followed at all sites on 7 cruises in 2005 and 2006 (28 March to 2 April, 21 to 26 May, 12 to 16 July, 29 September to 4 October, 5 to 10 November 2005, 13 to 17 February, 26 April to 5 May 2006). Zooplankton, infaunal invertebrates, epifaunal invertebrates and fish were sampled. Details of gear, sampling design, replication, gear efficiency and the size ranges of animals sampled are given in Table 1. To the extent possible, the sampling protocols have been developed to take random samples of species and individuals that fall within the lower and upper size bounds defined for each faunal group (Table 1).

Zooplankton were sampled with a high speed tow net deployed in a double oblique tow while steaming east-west or west-east at a speed of approximately 4 knots (Nash et al. 1998). The volume of water filtered was recorded with an internal flow meter. When the sampler was recovered, the end bag was removed and

Table 1. Sampling methods employed in the study of $\delta^{15} \mathrm{~N}$ seasonal variations. HSTN: high speed towed net, NIOZ: Netherlands Institute for Sea Research

\begin{tabular}{|c|c|c|c|c|c|c|c|c|c|}
\hline Group & Gear & Mesh & $\begin{array}{l}\text { Sites } \\
\text { per } \\
\text { cruise }\end{array}$ & $\begin{array}{c}\text { Replicates } \\
\text { per } \\
\text { site }\end{array}$ & $\begin{array}{c}\text { Replicate } \\
\text { sample } \\
\text { size }\end{array}$ & $\begin{array}{c}\text { Sampling } \\
\text { efficiency } \\
(\%)\end{array}$ & $\begin{array}{l}\text { No of } \\
\text { size } \\
\text { classes }\end{array}$ & $\begin{array}{l}\text { Size range } \\
\text { (g) }\end{array}$ & $\begin{array}{l}\text { Faunal } \\
\text { groups }\end{array}$ \\
\hline Zooplanktor & HSTN & $250 \mu \mathrm{m}$ & 8 & 1 & $394 \mathrm{~m}^{3, \mathrm{~b}}$ & 100 & $6^{\mathrm{c}}$ & $\begin{array}{c}0.0001- \\
0.003^{\mathrm{e}}\end{array}$ & All zooplankton \\
\hline Infauna & NIOZ corer & NA & 5 & 7 & $0.1 \mathrm{~m}^{2}$ & 100 & $10^{\mathrm{d}}$ & $0.0039-4$ & $\begin{array}{l}\text { Polychaetes } \\
\text { Crustacea } \\
\text { Asteroidea } \\
\text { Other }\end{array}$ \\
\hline Epifauna & $2 \mathrm{~m}$ beam trawl & $2 \mathrm{~mm}$ & 5 & 5 & $650 \mathrm{~m}^{2, \mathrm{~b}}$ & $40-51.2^{\mathrm{a}}$ & $5^{\mathrm{d}}$ & $0.5-16$ & $\begin{array}{l}\text { Crustacea } \\
\text { Echinoderms }\end{array}$ \\
\hline Fish $<8 \mathrm{~g}$ & $2 \mathrm{~m}$ beam trawl & $2 \mathrm{~mm}$ & 5 & 2 & $650 \mathrm{~m}^{2, \mathrm{~b}}$ & $32^{\mathrm{a}}$ & $5^{\mathrm{d}}$ & $0.5-16$ & All fish \\
\hline Fish $>8 \mathrm{~g}$ & $4 \mathrm{~m}$ beam trawl & $20 \mathrm{~mm}$ & 3 & 2 & $14824 \mathrm{~m}^{2, \mathrm{~b}}$ & 50 & $5^{\mathrm{d}}$ & $8-256$ & $\begin{array}{l}\text { Dab } \\
\text { Whiting } \\
\text { Other fish }\end{array}$ \\
\hline
\end{tabular}


a second end bag was attached for washing down the net. The contents of the first bag were used for size fractionation while the contents of the second were preserved with $4 \%$ formalin in seawater solution buffered with $3 \mathrm{~g} \mathrm{l}^{-1}$ sodium acetate trihydrate. The sample from the second bag was preserved to prevent algae that were trapped on the net from influencing the stable isotope analysis, while allowing us to ascertain the abundance of zooplankton that were not in the first bag. For size fractionation, the contents of the first bag were washed into a 21 jug using seawater. Samples were then washed in sequence through 6 sieves with mesh (nylon) sizes of 2000, 1400, 1000, 700, 500 and $250 \mu \mathrm{m}$. After sieving, the zooplankton retained in each sieve were washed onto squares (ca. $20 \mathrm{~cm}^{2}$ ) of fine nylon mesh $(10 \mu \mathrm{m})$, sealed in a plastic bag and frozen rapidly to $-20^{\circ} \mathrm{C}$. Freezing to $-20^{\circ} \mathrm{C}$ does not affect $\delta^{15} \mathrm{~N}$ (Sweeting et al. 2004). In the laboratory, frozen samples were defrosted and a sample of approximately 100 zooplankton individuals was removed from each mesh, counted and weighed (wet mass and dry mass). This subsample was used to determine the mean individual body mass of zooplankton in each size fraction at each site on each cruise. The remaining zooplankton on each mesh were weighed after blotting (wet body mass, to nearest $0.0001 \mathrm{~g}$ ), dried to constant mass at $40^{\circ} \mathrm{C}$ (dry mass, to nearest $0.0001 \mathrm{~g}$ ). The sample was then ground to a fine homogenous powder with a pestle and mortar (particles passed through a $60 \mu \mathrm{m}$ sieve) for stable isotope analysis. Zooplankton were sorted from the preserved (second bag) sample and dried to constant mass at $40^{\circ} \mathrm{C}$. The dry masses of the first and second bag samples were added to determine the total dry mass of each size fraction. Zooplankton mass was converted to biomass $\mathrm{m}^{-3}$ seawater by dividing total mass by the volume of water filtered.

Infauna were sampled with a Netherlands Institute for Sea Research (NIOZ) corer, which takes a circular sediment core of $0.1 \mathrm{~m}^{2}$ to a depth of approximately $0.5 \mathrm{~m}$ (McIntyre \& Eleftheriou 2005). Replicates were taken at randomly chosen positions within a $500 \mathrm{~m}$ radius of each site. All material retained by the corer was sieved through $1 \mathrm{~mm}$ square mesh and all retained infauna were spread out in a plastic bag and frozen immediately to $-20^{\circ} \mathrm{C}$. In the laboratory, samples were defrosted and animals sorted into Crustacea, Asteroidea, Polychaeta or 'others'. Animals were weighed individually (shell free mass for bivalves and spatangoids) and allocated to integer size classes on a $\log _{2}$ scale from $0.0039-0.0078 \mathrm{~g}$ to $2.0-4.0 \mathrm{~g}$ by group (pooling across replicates at each site). Animals in each group were then refrozen, freeze-dried to constant mass and reweighed. The freeze-dried material was ground to a fine homogenous powder (to pass through a $60 \mu \mathrm{m}$ sieve) for stable isotope analysis. Infaunal bio- mass was calculated by dividing the mass of animals in each sample by the area sampled.

Epifauna and small fish $(<16 \mathrm{~g}$ individual wet body mass) were sampled with a $2 \mathrm{~m}$ beam trawl (Jennings et al. 1999, Reiss et al 2006). Two $2 \mathrm{~m}$ beam trawls of 5 min duration (on seabed) at a speed of 1 knot were completed at each site and the catches pooled for processing. Catches were sorted into epifaunal invertebrates (groups 'echinoderms' and 'crustaceans') and fish. Individuals in each group were assigned to $\log _{2}$ integer size classes from $0.5-1.0$ to $8.1-16 \mathrm{~g}$, and total mass was recorded. Shells were removed from hermit crabs before weighing. Eight individuals (or all individuals if $<8$ ) were randomly selected from each size class and frozen to $-20^{\circ} \mathrm{C}$. In the laboratory these were freeze-dried to constant mass and this material was ground to a fine homogenous powder (to pass through a $60 \mu \mathrm{m}$ sieve) for stable isotope analysis. Epifaunal biomass was calculated by dividing the mass of animals in each sample, corrected for catchability (Table 1), by the area sampled by the gear (distance towed $\times$ beam width).

Larger fish (>8 g) were sampled with a $4 \mathrm{~m}$ beam trawl (Kaiser \& Spencer 1995). Two $30 \mathrm{~min}$ tows were completed at each site at a speed of 4 knots, starting at a random location on the trawl lines. Catches from the 2 tows were pooled for processing and the fish sorted into 'dab', 'whiting' and 'other demersal fish'. Individuals in each group were weighed, assigned to $\log _{2}$ integer size classes from 8.1-16 to 128-256 g, and total mass was recorded. Eight individuals (or all individuals if $<8$ ) were randomly selected from each size class and frozen to $-20^{\circ} \mathrm{C}$. Dorsal white muscle tissue was dissected from each of these individuals in proportion to body mass (tissue sample typically 1 to $20 \%$ of total body mass, depending on individual body mass) and tissue samples were combined within groups and size classes and frozen to $-20^{\circ} \mathrm{C}$. In the laboratory, the tissue was freeze-dried to constant mass and ground to a fine homogenous powder (to pass through a $60 \mu \mathrm{m}$ sieve) for stable isotope analysis.

Stable isotope data were collected for animals that were binned into body mass classes as determined by a progression of mesh sizes (zooplankton) or a $\log _{2}$ integer scale (all other fauna). These bins were selected to divide the fauna into a number of classes that would allow explorations of size and $\delta^{15} \mathrm{~N}$ relationships within faunal groups. However, all body mass classes were expressed on a $\log _{10}$ scale in the analyses, converted from $\log _{2}$ as $\log _{10} M=\log _{2} M \times \log _{10} 2$, where $M$ is body mass.

The ${ }^{15} \mathrm{~N}$ and ${ }^{13} \mathrm{C}$ compositions of samples were determined by continuous flow isotope ratio mass spectrometry (CF-IRMS). Samples and reference materials (Iso-Analytical working standard powdered bovine 
liver IA-R042) were weighed into tin capsules, sealed, and loaded into a Europa Scientific Roboprep-CN sample preparation module connected to a Europa Scientific 20-20 IRMS. Two samples of reference material were analysed after every 5 tissue samples to calibrate the system and compensate for drift. The ${ }^{15} \mathrm{~N}$ composition was expressed in conventional delta notation $\left(\delta^{15} \mathrm{~N}\right)$, relative to the level of ${ }^{15} \mathrm{~N}$ in atmospheric $\mathrm{N}_{2}$. Experimental precision was $<0.15 \%$ o (standard deviation for replicates of reference material).

To obtain values for $\delta^{15} \mathrm{~N}$ of all infauna, epifauna or fish, $\delta^{15} \mathrm{~N}$ was calculated as a biomass weighted mean of the values for component groups.

\section{RESULTS}

The $\delta^{15} \mathrm{~N}$ of zooplankton varied over the course of the production cycle (Fig. 1). For all zooplankton body mass classes, $\delta^{15} \mathrm{~N}$ was most depleted during the first cruise (28 March to 2 April 2005). At that time, there

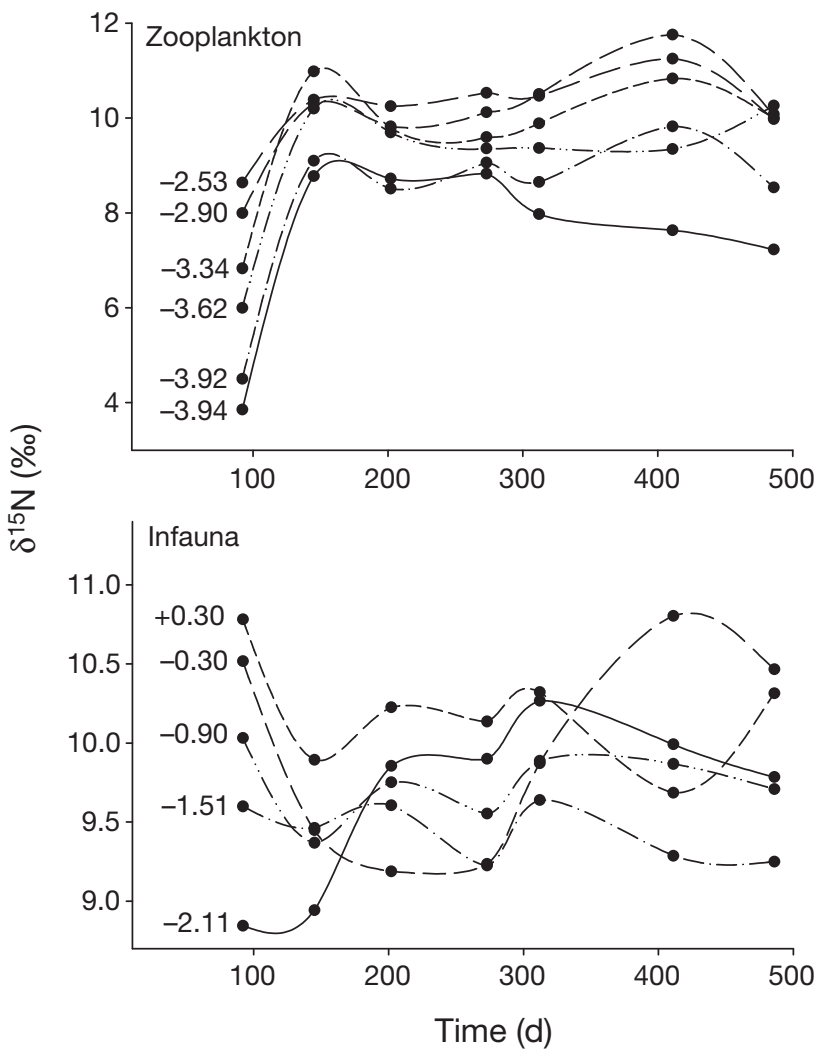

Fig. 1. Relationships between the $\delta^{15} \mathrm{~N}$ of zooplankton or infaunal size classes $\left(\log _{10}\right.$ midpoints of wet mass classes in $\mathrm{g}$ ) and the time of sampling. Time is the number of days from 1 January 2005 to the sampling day. Spline curves are fitted to the data for illustrative purposes only. For infauna, each time series shows the mean $\delta^{15} \mathrm{~N}$ for pairs of adjacent $\log _{2}$ body mass classes, with midpoints recalculated to $\log _{10}$ was a strong negative relationship between body mass and the extent of depletion. The $\delta^{15} \mathrm{~N}$ of all but the smallest body mass class of infauna was relatively enriched at this time (Fig. 1), but by the second cruise (21 to 26 May 2005) $\delta^{15} \mathrm{~N}$ was relatively depleted. During subsequent cruises, infaunal $\delta^{15} \mathrm{~N}$ fluctuated.

Temporal trends in $\delta^{15} \mathrm{~N}$ for other body mass classes and faunal groups were not as consistent as those for zooplankton and infauna. A simple analysis that tracked the day when the most depleted $\delta^{15} \mathrm{~N}$ value was recorded for each body mass class or faunal group showed that this day tended to be later, but not consistently later, for larger body mass classes and groups other than zooplankton (Fig. 2). However, the weak correspondence between temporal trends belies strong and consistent relationships between the magnitude of variability over time, body mass and mean $\delta^{15} \mathrm{~N}$ (Fig. 3). Thus, seasonal variation in $\delta^{15} \mathrm{~N}$, as indicated by the $\mathrm{CV}$ (coefficient of variation) of $\delta^{15} \mathrm{~N}$ among cruises, decreased progressively with body mass and increasing $\delta^{15} \mathrm{~N}$ (Fig. 3). For animals $\geq 16 \mathrm{~g}$, $\mathrm{CV}$ was always $<3 \%$, whereas for animals of 0.5 to $16 \mathrm{~g}, \mathrm{CV}$ did not exceed $11 \%$.

Mean $\delta^{15} \mathrm{~N}$ of zooplankton (among cruises) was significantly related to body mass (Fig. 4). Assuming $3.4 \%$ o fractionation in $\delta^{15} \mathrm{~N}$ per trophic level, the slope of this relationship (1.67) implies a predator-prey mass ratio (PPMR) in this community of 109:1 (where PPMR $\left.=10^{3.4 / \text { slope }}\right)$. However, when these slopes were calculated from data for individual cruises, they varied considerably from 0.93 on 12 to 16 July 2005 to 2.75 on 28 March to 2 April 2005, reflecting seasonal variability in $\delta^{15} \mathrm{~N}$ at size (Fig. 1), and illustrating the biases that can be introduced by not accounting for seasonal dynamics in food web studies. The PPMR calculations assume that samples are representative of all zoo-

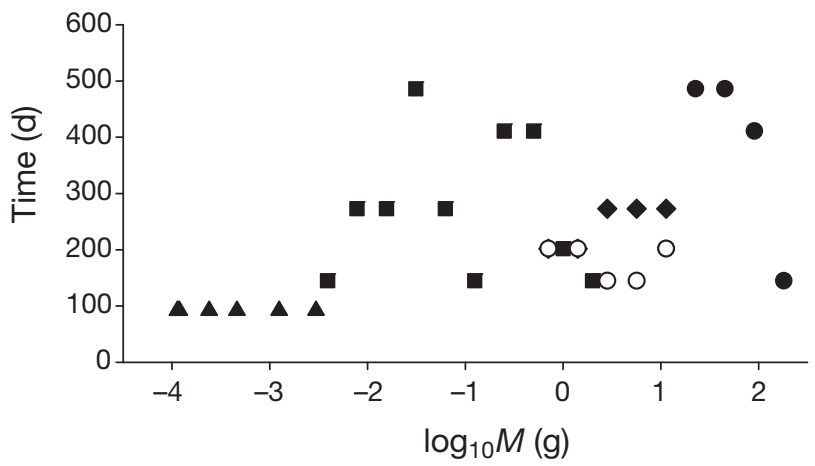

Fig. 2. Relationship between body mass $(M)$ and the day when the lowest $\delta^{15} \mathrm{~N}$ was recorded. Data are only presented if $M$ ( $\log _{10}$ midpoints of wet mass classes in $\mathrm{g}$ ) and faunal group were sampled on all 7 cruises. Time is the number of days from 1 January 2005 to the sampling day. $\mathbf{\Delta}$ : zooplankton, $\mathbf{\square}$ : infauna, $\bullet$ : epifaunal invertebrates, O: fish ( $2 \mathrm{~m}$ beam trawl) and $\bullet$ : fish ( $4 \mathrm{~m}$ beam trawl) 


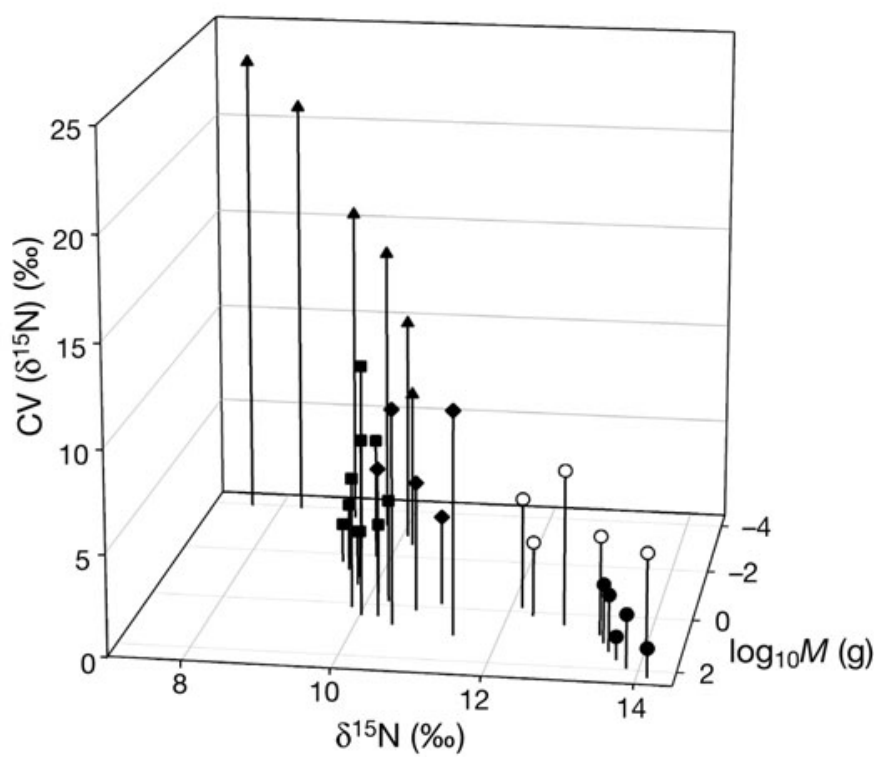

Fig. 3. Relationships between mean $\delta^{15} \mathrm{~N}, \delta^{15} \mathrm{~N} C V$ (coefficient of variation, reflecting variation in $\delta^{15} \mathrm{~N}$ through time) and body mass $(M$, midpoints of wet mass classes in $g$ ) for the sampled faunal groups. $\mathbf{\Delta}$ : zooplankton, $\mathbf{\square}$ : infauna, $\bullet$ : epifaunal invertebrates, 0 : fish $(2 \mathrm{~m}$ beam trawl) and $\mathrm{O}$ : fish (4 $\mathrm{m}$ beam trawl) plankton in the size classes considered. This is likely given the double oblique hauls conducted, since these tows sampled approximately equal volumes of water at all depths. Recorded wet mass to dry mass ratios were quite consistent for zooplankton, ranging from 6.2 to 7.6 across all body mass classes within cruises and were not related to the day of sampling.

For the whole infaunal community, the slope of the relationship between $\delta^{15} \mathrm{~N}$ and body mass was not significantly different from zero $(<0.05)$. However, component groups showed different relationships, with Polychaeta increasing in $\delta^{15} \mathrm{~N}$ with body mass, while Asteroidea and Crustacea did not show consistent trends. The $\delta^{15} \mathrm{~N}$ of polychaetes was higher at size than that of other infaunal groups (Fig. 4). For epifauna, the $\delta^{15} \mathrm{~N}$ of the whole invertebrate community was not related to body mass, while there was a strong relationship for fish. For the community of larger fish sampled with the $4 \mathrm{~m}$ beam trawl, the relationship between $\delta^{15} \mathrm{~N}$ and body mass was significant $(<0.05)$. The variable relationships between body mass and $\delta^{15} \mathrm{~N}$ in these groups, which span relatively small size ranges, belie a stronger relationship when all body mass classes are considered (Fig. 5). Larger animals
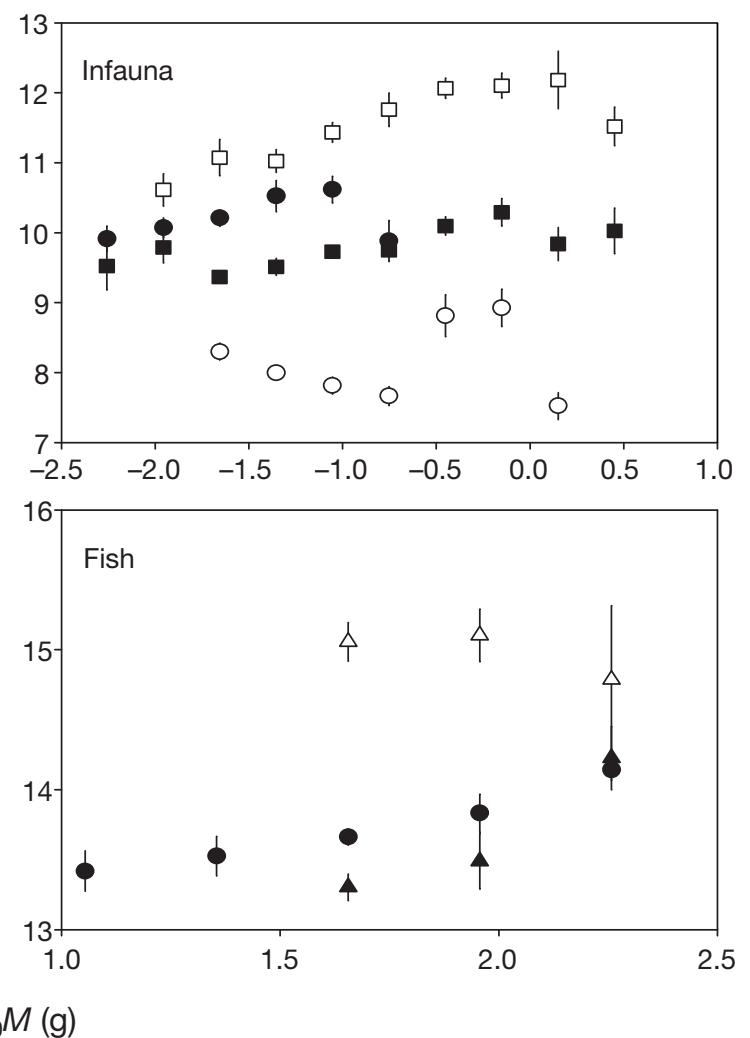

Fig. 4. Relationships between $\delta^{15} \mathrm{~N}$ and body mass ( $M$, midpoints of wet mass classes in $\mathrm{g}$ ) for the sampled faunal groups (mean \pm $\mathrm{SD}$ ). Fitted lines are linear relationships (95\% CI for slope) between $\delta^{15} \mathrm{~N}$ and body mass for zooplankton. For infauna, $\bullet$ : Asteroidea, ○: Crustacea, $\square$ : Polychaeta and $\mathbf{\square}$ : all infauna. For epifauna, ๑: Asteroidea, O: Crustacea, $\square$ : fish and $\bullet:$ all invertebrate epifauna. For fish, $\mathbf{\Delta}$ : dab, $\Delta$ : whiting and $\bullet$ : all fish 


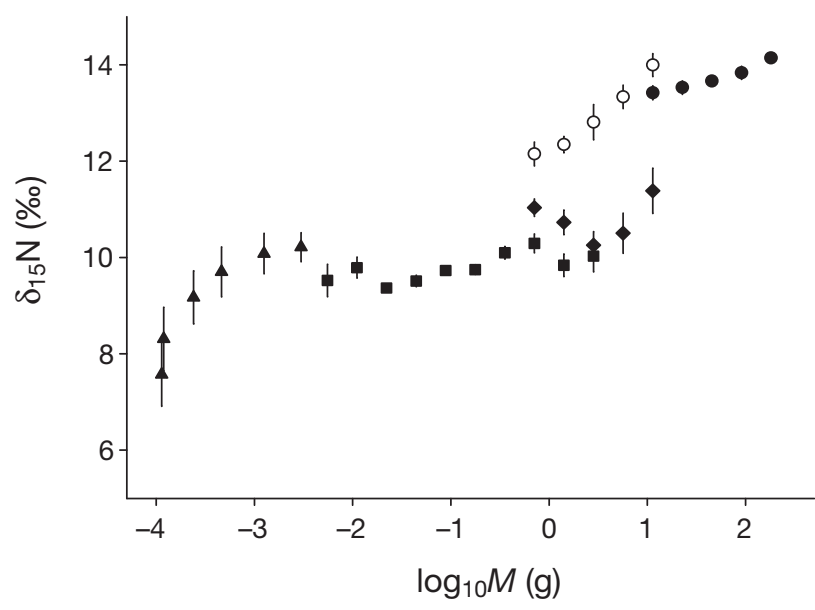

Fig. 5. Relationships between $\delta^{15} \mathrm{~N}$ (mean $\pm \mathrm{SD}$ ) and body mass $(M$, midpoints of wet mass classes in $\mathrm{g}$ ) for the sampled faunal groups. $\mathbf{\Delta}$ : zooplankton, $\mathbf{\square}$ : infauna, $\bullet$ : epifaunal invertebrates, O: fish ( $2 \mathrm{~m}$ beam trawl) and $\bullet$ : fish $(4 \mathrm{~m}$ beam trawl)

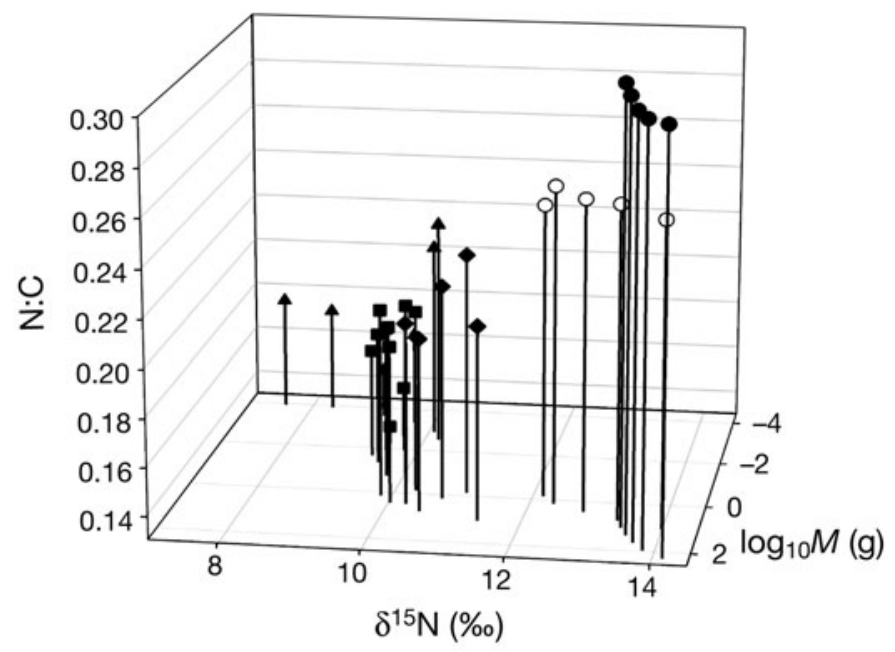

Fig. 6. Relationships between mean $\delta^{15} \mathrm{~N}$, body mass $(M$, midpoints of wet mass classes in $\mathrm{g}$ ) and the $\mathrm{N}$ :C (nitrogen: carbon) ratio of the sampled faunal groups. $\mathbf{\Delta}$ : zooplankton, 口: infauna, : epifaunal invertebrates, O: fish $(2 \mathrm{~m}$ beam trawl) and : fish (4 $\mathrm{m}$ beam trawl)

at higher trophic levels also had higher $\mathrm{N}: \mathrm{C}$ ratios (Fig. 6).

Mean surface temperatures (recorded during zooplankton sampling) ranged from $6.1^{\circ} \mathrm{C}$ from 28 March to 2 April 2005 to $15.5^{\circ} \mathrm{C}$ from 29 September to 4 October 2005, and bottom temperature from 5.7 to $15.4^{\circ} \mathrm{C}$ on the same dates. Overall mean temperatures, based on the cruise data, were $10.6^{\circ} \mathrm{C}$ (surface) and $9.4^{\circ} \mathrm{C}$ (bottom).

\section{DISCUSSION}

Zooplankton $\delta^{15} \mathrm{~N}$ was relatively depleted in all size classes at the start of the study period, but absolute depletion was less in larger size classes. This may be attributed to maximum depletion occurring later in the year in larger zooplankton and/or to lower potential depletion in larger zooplankton owing to their slower turnover times and mixed diets (phytoplankton and smaller zooplankton). The $\delta^{15} \mathrm{~N}$ of infauna was relatively high when the zooplankton signature was depleted, suggesting that the pelagic $\delta^{15} \mathrm{~N}$ signal had not yet influenced the benthic community. However, when the food web was sampled approximately 50 d later, the zooplankton signal was relatively enriched while the infaunal signal was relatively depleted. This implies that pelagic production had reached the seabed and had been consumed by infauna. Further evidence for the availability of food of pelagic origin to the infauna was provided by high concentrations of sediment chlorophyll and phaeopigment on the second sampling date (M. Schratzberger unpubl. data).

These time- and size-related trends in $\delta^{15} \mathrm{~N}$ did not propagate to other parts of the food web at a consistent rate. This is not surprising given the relatively small magnitude of the signal reaching the infauna and the fact that different parts of the food web assimilate energy in different ways and process it at different speeds. For example, the relationships between body size and mean $\delta^{15} \mathrm{~N}$ imply that Asteroidea and Crustacea feed at similar trophic levels regardless of body size, and that all size classes share and/or compete for the energy available at these trophic levels. For Polychaeta, conversely, $\delta^{15} \mathrm{~N}$ was relatively high and increased with size, implying a predation-based food chain consistent with knowledge of dietary habits (e.g. Beukema 1987). These different energy pathways mean that $\delta^{15} \mathrm{~N}$ variations do not remain in phase throughout the food web, and while the data show lagged responses of larger size classes to the depleted zooplankton signal, the timing of these responses was very variable. Theorists have predicted that the existence and coupling of these 'slow' and 'fast' energy pathways increase the stability of food webs (Rooney et al. 2006).

Notwithstanding the uneven propagation of $\delta^{15} \mathrm{~N}$ signals through the food web, temporal variation in $\delta^{15} \mathrm{~N}$ within and among groups decreased consistently with body size. Two processes could account for $\delta^{15} \mathrm{~N}$ variation in consumers: changes in the trophic level of diet and changes in $\delta^{15} \mathrm{~N}$ that are independent of the trophic level of the diet. Since the smallest zooplankton classes are principally phytoplankton consumers, and phytoplankton would be assigned a fixed trophic level of 1 in food web analysis, all variation in herbivorous 
zooplankton $\delta^{15} \mathrm{~N}$ is expected to be independent of variation in true trophic level.

Temporal variation in $\delta^{15} \mathrm{~N}$ was significantly greater in smaller animals and declined continuously with body size. All animals $\geq 16 \mathrm{~g}$ wet mass effectively integrated the $\delta^{15} \mathrm{~N}$ seasonal variation of their prey; thus, a single annual sampling of animals $\geq 16 \mathrm{~g}$ is adequate to determine mean $\delta^{15} \mathrm{~N}$ in food web interaction and source studies at this North Sea site, where mean sea surface and bottom temperatures during the study period were 10.6 and $9.4^{\circ} \mathrm{C}$, respectively. Temporal variation in $\delta^{15} \mathrm{~N}$ will, in part, reflect variability in turnover time, which is linked to metabolism and dependent on body size and temperature (Brown et al. 2004). Thus the size threshold for annual sampling, or the requirement for repeated sampling through the year, is expected to increase with increasing temperature for a given pattern of variation in the $\delta^{15} \mathrm{~N}$ of primary producers.

The observed reductions in $\delta^{15} \mathrm{~N}$ variation with size are consistent with predicted reductions in turnover time with size. Denman et al (1989), for example, used a size-based model to estimate time scales for transfer of energy from primary producers to small zooplankton, larger zooplankton and juvenile and adult fish. Predicted times were $25 \mathrm{~d}$ for copepods (mass $0.0025 \mathrm{~g}), 90 \mathrm{~d}$ for euphausid-sized zooplankton (0.4 g), $270 \mathrm{~d}$ for juvenile fish $(30 \mathrm{~g})$ and $650 \mathrm{~d}$ for adult fish (100 g).

The importance of understanding and accounting for $\delta^{15} \mathrm{~N}$ variation in food web analysis was illustrated by the PPMR calculations. When the slopes were calculated using mean $\delta^{15} \mathrm{~N}$ for all cruises, the slope of 1.67 implied a PPMR of 109:1, almost identical to the value estimated for larger animals (including pelagic fish) in a previous study of the central North Sea food web (Jennings et al. 2002b). However, if PPMR had been estimated using data from individual cruises, the slopes would have varied from 0.93 to 2.75 and provided unrealistic estimates of mean PPMR (4528 and 17 , respectively).

$\Delta \delta^{15} \mathrm{~N}$, the mean fractionation of $\delta^{15} \mathrm{~N}$ per trophic level, is often assumed to be around 3.4\% (Minagawa \& Wada 1984, McCutchan et al 2003) and this value is consistent with the mean value for fish white muscle (3.15\%, Sweeting et al 2007), even though there is variation around the mean for fish that is attributable to species and environmental effects (Barnes et al. 2007, Sweeting et al. 2007). Such variation would not alter our conclusions about the effects of body size on $\delta^{15} \mathrm{~N}$ variance, unless $\Delta \delta^{15} \mathrm{~N}$ systematically decreased with body size, an effect that has not been observed.

Larger body size and higher trophic level were associated with higher $\mathrm{N}: \mathrm{C}$ ratios. This implies that the tissues of smaller animals contained more lipids, since lipids contain no N. Storage of lipids is well known and documented in small animals such as zooplankton (Lee et al 2006). Variations in lipid content influence the results of $\delta^{13} \mathrm{C}$ analysis because lipids are $\delta^{13} \mathrm{C}$ depleted relative to proteins (Focken \& Becker 1998), and a number of techniques is available to correct for these effects when using $\delta^{13} \mathrm{C}$ data in food web studies (Sweeting et al. 2006, Ingram et al. 2007).

The substantial seasonal fluctuations in $\delta^{15} \mathrm{~N}$ show that the $\delta^{15} \mathrm{~N}$ of single samples of small animals should not be used to draw conclusions about the trophic role of those animals in the food web. If trophic levels are to be estimated for small animals, or if their $\delta^{15} \mathrm{~N}$ is to be used as base $\delta^{15} \mathrm{~N}$, then repeated intra-annual sampling will be needed. Given the variability we have observed, as well as the variability reported elsewhere, routine measurements of the mean $\delta^{15} \mathrm{~N}$ of zooplankton would be logistically and analytically challenging. To calculate base $\delta^{15} \mathrm{~N}$, the alternative is to use animals such as bivalve molluscs (e.g. Goering et al. 1990, Cabana \& Rasmussen 1996, Lorrain et al. 2002) or large fish (e.g. Layman et al. 2005) for which a trophic level can be assigned and which integrate the short-term and spatial $\delta^{15} \mathrm{~N}$ variability of their diets. However, even if base $\delta^{15} \mathrm{~N}$ can be defined, the relative trophic levels of the animals in relation to base $\delta^{15} \mathrm{~N}$ will only be estimated precisely when the sampling scheme accounts for temporal variability in $\delta^{15} \mathrm{~N}$. A sampling scheme that accounted for temporal variability would have been necessary for animals of 0.5 to $16 \mathrm{~g}$ in the present study, where the $\mathrm{CV}$ of 3 to $11 \%$ equated to a standard deviation of 0.3 to $1.1 \%$ (if mean $\delta^{15} \mathrm{~N}$ were $10 \%$ ). While $0.3 \%$ approaches the precision of the $\delta^{15} \mathrm{~N}$ analysis, $1.1 \%$ is equivalent to around $1 / 3$ of a trophic level.

Acknowledgements. We thank the officers and crew of Cefas Endeavour, A. Meadows, B. Harley, C. Houghton, C. Burt, C. Firmin, C. Mills, D. Pearce, E. Lane, J. Keable, J. Ellis, J. Blanchard, K. Warr, M. Eade, M. Shaw, M. Boon, N. Taylor, N. Dulvy, N. Lyman, P. Eastwood and R. Mitchell for their contributions to the cruise programme, S. Cogan and M. Shaw for processing samples, C. Belanger and Iso-analytical colleagues for conducting the nitrogen stable isotope analyses, the (anonymous) referees for providing some helpful suggestions that led to substantial changes to the analyses and text, and the UK Department of Environment, Food and Rural Affairs for funding.

\section{LITERATURE CITED}

Barnes C, Sweeting CJ, Jennings S, Barry JT, Polunin NVC (2007) Effect of temperature and ration size on carbon and nitrogen stable isotope fractionation. Funct Ecol 21: $356-362$

> Beukema JJ (1987) Influence of the predatory polychaete Nephtys hombergii on the abundance of other polychaetes. Mar Ecol Prog Ser 40:95-101

Bode A, Alvarez-Ossorio MT (2004) Taxonomic versus trophic 
structure of mesozooplankton: a seasonal study of species succession and stable carbon and nitrogen isotopes in a coastal upwelling ecosystem. ICES J Mar Sci 61:563-571

Bode A, Carrera P, Lens S (2003) The pelagic foodweb in the upwelling ecosystem of Galicia (NW Spain) during spring: natural abundance of stable carbon and nitrogen isotopes. ICES J Mar Sci 60:11-22

Bode A, Alvarez-Ossorio MT, Cunha E, Garrido S and others (2007) Stable nitrogen isotope studies of the pelagic food web on the Atlantic shelf of the Iberian Peninsula. Prog Oceanogr 74:115-131

Brown JH, Gillooly JF, Allen AP, Savage VM, West GB (2004) Towards a metabolic theory of ecology. Ecology 85: 1771-1789

Cabana G, Rasmussen JB (1996) Comparison of aquatic food chains using nitrogen isotopes. Proc Natl Acad Sci USA 93:10844-10847

Denman KL, Freeland HJ, Mackas DL (1989) Comparisons of time scales for biomass transfer up the marine food web and coastal transport processes. Can Spec Pub Fish Aquat Sci 108:255-264

Focken U, Becker K (1998) Metabolic fractionation of stable carbon isotopes: implications of different proximate compositions for studies of the aquatic food webs using $\delta^{13} \mathrm{C}$ data. Oecologia 115:337-343

Fry B (2006) Stable isotope ecology. Springer, New York

> Goering J, Alexander V, Haubenstock N (1990) Seasonal variability of stable carbon and nitrogen isotope ratios of organisms in a North Pacific bay. Estuar Coast Shelf Sci 30:239-260

Ingram T, Matthews B, Harrod C, Stephens T, Grey J, Markel R (2007) Lipid extraction has little effect on the $\delta^{15} \mathrm{~N}$ of aquatic consumers. Limnol Oceanogr Methods 5: 338-343

Jennings S, Lancaster JE, Woolmer A, Cotter AJ (1999) Distribution, diversity and abundance of epibenthic fauna in the North Sea. J Mar Biol Assoc UK 79:385-399

> Jennings S, Pinnegar JK, Polunin NVC, Warr KJ (2002a) Linking size-based and trophic analyses of benthic community structure. Mar Ecol Prog Ser 226:77-85

> Jennings S, Warr KJ, Mackinson S (2002b) Use of size-based production and stable isotope analyses to predict trophic transfer efficiencies and predator-prey body mass ratios in food webs. Mar Ecol Prog Ser 240:11-20

Kaiser M, Spencer BE (1995) Survival of by-catch from a beam trawl. Mar Ecol Prog Ser 126:31-38

- Layman CA, Winemuller KO, Arrington DA, Jepsen DB (2005) Body size and trophic position in a diverse tropical food web. Ecology 86:2530-2535

Lee RF, Hagen W, Kattner G (2006) Lipid storage in marine zooplankton. Mar Ecol Prog Ser 307:273-306

Lorrain A, Paulet YM, Chauvaud L, Savoye N, Donval A, Saout C (2002) Differential $\delta^{13} \mathrm{C}$ and $\delta^{15} \mathrm{~N}$ signatures among scallop tissues: implications for ecology and physiology. J Exp Mar Biol Ecol 275:47-61

Matthews B, Mazumder A (2005) Temporal variation in body composition (C:N) helps explain seasonal patterns of zooplankton $\delta^{13} \mathrm{C}$. Freshw Biol 50:502-515

Matthews B, Mazumder A (2007) Distinguishing trophic variation from seasonal and size-based isotopic $\left(\delta^{15} \mathrm{~N}\right)$ variation of zooplankton. Can J Fish Aquat Sci 64:74-83

Editorial responsibility: Peter Verity,

Savannah, Georgia, USA
McCutchan JH, Lewis WM, Kendall C, McGrath CC (2003) Variation in trophic shift for stable isotope ratios of carbon, nitrogen, and sulfur. Oikos 102:378-390

McIntyre AD, Eleftheriou A (2005) Methods for the study of marine benthos. Blackwell Publishing, Oxford

Minagawa M, Wada E (1984) Stepwise enrichment of ${ }^{15} \mathrm{~N}$ along food chains: further evidence and the relation between $\delta^{15} \mathrm{~N}$ and animal age. Geochim Cosmochim Acta 48:1135-1140

Montoya JP, Horrigan SG, McCarthy JJ (1990) Natural abundance of ${ }^{15} \mathrm{~N}$ in particulate nitrogen and zooplankton in the Chesapeake Bay. Mar Ecol Prog Ser 65:35-61

> Nash RDM, Dicky-Collas M, Milligan SP (1998) Descriptions of the Gulf VII/ PRO-NET and MAFF/Guildline unencased high-speed plankton samplers. J Plankton Res 20: 1915-1926

O'Reilly CM, Hecky RE, Cohen AS, Plisnier PD (2002) Interpreting stable isotopes in food webs: recognizing the role of time averaging at different trophic levels. Limnol Oceanogr 47:306-309

Owens NJP (1987) Natural variations in ${ }^{15} \mathrm{~N}$ in the marine environment. Adv Mar Biol 24:389-451

Reiss H, Kroncke I, Ehrich S (2006) Estimating the catching efficiency of a 2-m beam trawl for sampling epifauna by removal experiments. ICES J Mar Sci 63:1453-1464

Rolff C (2000) Seasonal variation in $\delta^{13} \mathrm{C}$ and $\delta^{15} \mathrm{~N}$ of size-fractionated plankton at a coastal station in the northern Baltic proper. Mar Ecol Prog Ser 203:47-65

Rooney N, McCann K, Gellner G, Moore JC (2006) Structural asymmetry and the stability of diverse food webs. Nature 442:265-269

> Sato T, Miyajima T, Ogawa H, Umezawa Y, Koike I (2006) Temporal variability of stable carbon and nitrogen isotopic composition of size-fractionated particulate organic matter in the hypertrophic Sumida River Estuary of Tokyo Bay, Japan. Estuar Coast Shelf Sci 68:245-258

> Sweeting CJ, Polunin NVC, Jennings S (2004) Tissue and fixative dependent shifts of $\delta^{13} \mathrm{C}$ and $\delta^{15} \mathrm{~N}$ in preserved ecological material. Rapid Comm Mass Spectrometry 18: 2587-2592

> Sweeting CJ, Polunin NVC, Jennings S (2006) Effects of chemical lipid extraction and arithmetic lipid correction on stable isotope ratios of fish tissues. Rapid Comm Mass Spectrometry 20:595-601

> Sweeting CJ, Barry J, Barnes C, Polunin NVC, Jennings S (2007) Effects of body size and environment on diet-tissue $\delta^{15} \mathrm{~N}$ fractionation in fishes. J Exp Mar Biol Ecol 340:1-10

> Vander Zanden MJ, Rasmussen JB (1999) Primary consumer $\delta^{13} \mathrm{C}$ and $\delta^{15} \mathrm{~N}$ and the trophic position of aquatic consumers. Ecology 80:1395-1404

Vizzini S, Mazzola A (2003) Seasonal variations in the stable carbon and nitrogen isotope ratios $\left({ }^{13} \mathrm{C} /{ }^{12} \mathrm{C}\right.$ and $\left.{ }^{15} \mathrm{~N} /{ }^{14} \mathrm{~N}\right)$ of primary producers and consumers in a western Mediterranean coastal lagoon. Mar Biol 142:1009-1018

Weston K, Jickells TD, Fernand L, Parker ER (2004) Nitrogen cycling in the southern North Sea: consequences for total nitrogen transport. Estuar Coast Shelf Sci 59:559-573

Yoshioka Y, Wada E, Hayashi H (1994) A stable isotope study on seasonal food web dynamics in a eutrophic lake. Ecology 75:835-846

Submitted: February 6, 2008; Accepted: July 12, 2008

Proofs received from author(s): October 15, 2008 